\title{
Model of Relationship Marketing Partnerships Between Batik SMEs and Batik Distributors in Central Java, Indonesia
}

\author{
Farida Naili, Diponegoro University, Semarang, Indonesia \\ Agus Naryoso, Diponegoro University, Semarang, Indonesia \\ Elia Ardyan, Sekolah Tinggi Ilmu Ekonomi Surakarta, Semarang, Indonesia
}

\begin{abstract}
This article develops and tests the model for the determinants of satisfaction and loyalty. The aim of this study is to analyze: (1) the effect of confident on relationship quality, (2) the effect of confidence on mutual benefit, (3) the effect of mutual benefit on relationship quality, (4) the effect of relationship quality on satisfaction, (5) the effect of mutual benefit on satisfaction, (6) the effect of mutual benefit on loyalty, and (7) the effect of satisfaction on loyalty. This model was tested using data obtained from 131 batik dealers in Semarang, Indonesia. The hypotheses are tested using Partial Least Square (PLS), all supported by the results of the confirmation of confidence, mutual benefit, which are found to be the key drivers of relationship quality, satisfaction and loyalty. This study emphasizes the role of relationship quality and mutual benefit as mediation for the variables of confidence and loyalty. The implications of the findings in this research towards the application of relationship marketing are: First, effort should be made to increase the confidence between suppliers and dealers who help market the product. Second, to ensure a long-term partnership between the enterprising parties, the quality of relationship between suppliers and craftsmen or Small and Medium Enterprises (SMEs) should be enhanced, so that the satisfaction of craftsmen or SMEs will be the better. Third, Craftsmen or SMEs should be more transparent in determining the mutual benefit with suppliers to improve satisfaction so as to create a profitable partnership for both enterprising parties. Fourth, satisfaction of dealers with craftsmen or SMEs should be increased so that the craftsman or SMEs can provide and meet the required product requested by the dealers in a timely manner.
\end{abstract}

\section{KEYWORDS}

Confidence, Mutual Benefit, Relationship Marketing, Relationship Quality, Satisfaction and Loyalty

\section{INTRODUCTION}

The profile of industrial sector in Central Java batik comprises of 8231 small and medium enterprises engaging in the creative industry, with a workforce of 43,589 people and a total investment of Rp. $844,0083,301,000$. In the city of Semarang currently exist 40 SMEs involved in Batik Semarangan, with a workforce of 149 people (Disperindag, Central Java, 2011-2014). Semarang city has many 
Small and Medium Enterprises (SMEs) active in the creative industry namely batik, embroidery, fashion, food and beverage all across Semarang. From development of Batik Small and Medium Enterprises (SMEs) data in Semarang, actual sales targets of batik production are still low in figure with 2007 target amounted to 20,150 units / fabric which increased up to 2010 target which amounted to 65,802 units / fabric, while in 2011 the target of batik production decreased to 58,350 units / fabric, to 57,120 units / fabric in 2012. Steady increase was found in 2013 figure of 78,208 and in 2014 with 86,761 units / fabric. The marketing activity for this business is confirmed to be fluctuating in nature.

The problem in Batik SMEs in Semarang lies in the inefficient market absorption of products, leaving manufacturers difficult to market their products to market. Distribution channel of the system still uses the old pattern that is an intermediary marketing through distributors, wholesalers or retailers. Therefore, existing cooperation and partnerships are largely based on relationship marketing, so partnerships between SMEs, distributors, wholesalers and retailers are expected to run well and mutually beneficial.

The results showed that the client relationship and commitment, Word of Mouth significantly affect satisfaction, yet transparency does not play significant role on the quality of relationships (Basheer, 2014). Findings of Crucere and Moise (2014) confirm that the sales force, sales activities, profits orientation are all performed to maintain customer loyalty by building a mutually beneficial and sustainable relationship. Kanibir (2014), in his research, explains that there are ways which can improve marketing performance of SMEs in the context of international marketing. Marketing relationships are further supported with research findings of Jia and Wang (2013) which mention that confidence of marketing channels can strengthen can strengthen relationship marketing which helps companies adapt to various market environments. Furthermore, Brettel (2012) presents the findings of a study to test the design of relationship marketing business model which support the notion that there is a positive increase in the relationship between the companies and the customers. Other findings from Farida (2017) and Palmatier (2007) shows that the quality of the relationship, perceived control among buyers, sellers, and businesses has a positive effect on the financial results of the businesses. In agreement with the former is a further research (Ardyan et al., 2016) which confirms that collaboration and business networking is important in conducting collaborative relationships between sellers and buyers through the marketing mediator within marketing channels namely distributor, wholesaler, and retailer. Results in studies by Kumar (2009) find that strengthening the implementation of marketing strategies is carried out through marketing relationships which promote satisfaction, retention, and loyalty. The importance of the quality of the relationships is also confirmed by Skarmeas (2008) who states that the quality of the relationships between import and export distributors is positively related to investment and performance.

This study differs from previous studies in that it implements relationship marketing; the quality of the relationship between producers or SMEs with dedicated distributors in Indonesia; craftsmen enconfidence their products to be marketed by distributors and in turn they receive the sales result. This study develops and tests the model for the determinants of satisfaction and loyalty. The aim of this study is to analysis: (1) the effect of confident on relationship quality, (2) the effect of confidence on mutual benefit, (3) the effect of mutual benefit on relationship quality, (4) the effect of relationship quality on satisfaction, (5) the effect of mutual benefit on satisfaction, (6) the effect of mutual benefit on loyalty, and (7) the effect of satisfaction on loyalty. The model confirms that the confidence factor serves as an important foundation in building sustainable relationships and cooperation.

The structure in this paper are as follows: (1) introduction; (2) literature review; (3) research methods; (4) the results of hypothesis testing; (5) research finding and theoretical implication.

\section{LITERATURE REVIEW}

The traditional marketing paradigm from the 90s only involved two parties, namely the seller and the buyer, whose relationship between them ends as the transaction closes. However, new paradigms in 
marketing show that there is a marked shift from transactional marketing into relationship marketing (Dwyer et al., 1987; Morgan \& Hunt, 1994; Palmer, 1994; Lin et al., 2003). In the context of this study, such relationship means the interaction between SMEs and craftsmen or dealers or marketing intermediaries, such as wholesalers or retailers, who sell products directly to consumers. Furthermore, Buttle (2007) states that relationship marketing is strategy that integrates internal processes and functions and external networks to provide value to the customer to earn profit.

Success in marketing batik products depends on the strength of distribution channels, i.e. craftsmen or SMEs as manufacturers of product and on the behavior of the dealer or marketing intermediaries, so the craftsmen or manufacturers must keep and maintain a continuous and long-term partnership with the dealer. Cooperation should be fostered between craftsmen or producers and marketing intermediaries, namely dealers grouped by the form relationships through distribution channels. Cooperation formed between craftsmen, as product manufacturers, and wholesalers or retailers, as dealers, are partnerships with focus on Business- to-consumer (B2C) business relationship as well as Business-to-Business (B2B) relationship marketing.

Relationship marketing activities are described as continuous, evolving, ties with interest so as to maintain the relationship between the company and customers (Berry, 1983; Berry \& Parasuraman, 1991; and Grönroos, 1994). This is supported by a change in the tendency of marketing and important benefits to building relationships with customers. In addition, relationship marketing as a driver of marketing approach is gaining more and more significance today (Grönroos, 1994). On the other hand, Lindgreen and Antioco (2003) states that the principal difference between marketing attributes with transactional marketing approach is to attribute 4P, namely Product, Price, Place and Promotion. This is different from relationship marketing in that relationship marketing uses 6 attributes namely: actor, marketing changes, the interaction between marketing actors, duration of marketing changes, structural attributes of the market, and marketing approaches.

Customer relationship marketing focus is the relationship between the company and the customers (B2C), whereas relationship marketing is a relationship between the company and the company or supplier as a partner to market products (B2B). Accordingly, Morgan and Hunt (1994) states that confidence and commitment are both key in any exchange between parties in relationship marketing, while Doney and Cannon (1997) states that only one of the two, either confidence or commitment alone, really matters.

Research results by Garbarino and Johnson (1999) shows that the quality of the relationship between the company and partners is reflected in the level of confidence the partners have on the company. Further research findings of Morgan and Hunt (1994) states that confidence is a central concept in relationship marketing. De Wulf and Odeskeben (2000) explain that the orientation of the relationship has a significant relationship on confidence. Consumer confidence can be stimulated through awards and distinctions. Both have a positive relationship with confidence. Relationship orientation significantly affects commitment, which in turn influences loyalty behavior. The research also finds how successful long-term relationship between the company and the dealer can be assessed by measuring partner relationships by loyalty and word of mouth communication, or WOM, in combination with three advantages namely self-confidence, social benefits, and special benefits from the company. These facts show that the share of the profits will affect the relationship between parties, or in the case of this study, between the company and dealers or craftsmen (Henning-Thurau et al., 2002).

Satisfaction can be built on confidence and quality of relationships between companies and suppliers to the partnership. In this study, overall satisfaction in terms of service, price, and overall fulfills the objective of cooperation between the companies and their partners, and is able to give collective satisfaction to the retailers or dealers and the company (Andersen et al., 1990).

Based on these descriptions a hypothesis can be built that studies conducted Bitner (1995) states that both the seller and the buyer present an opportunity to build or destroy that confidence. Smith (1998) explains that the relationship with the partner in question, a mutually beneficial relationship 
between producer and distributor or intermediary marketing, takes form in a mutual benefit between the company and the dealer.

De Wulf and Odeskeben (2000) explain that relationship orientation has a significant effect on confidence. Consumer confidence can be stimulated through awards and distinctions have a positive relationship with confidence. Furthermore, research findings by Robinetee (2000) maintain that all parties should be mutually benefited from the relationship with the company so that they are satisfied and happy with the products and services. Based on the description above, the constructed hypothesis is:

H1: Confidence affects the quality of the relationship.

Srikandi (2007) indicates that the mutual benefit is positively and significantly related the quality of the relationship, meaning that the higher the mutual benefit received, the better the quality of the relationship between the company and the dealer or marketing intermediaries. Based on the description above, the built hypothesis is:

H2: Confidence affects mutual benefit.

A study by Barnes (2003) confirms that a company develops a relationship with the customer is based on corporate profits, engagement with customers, and is strictly driven by financial reasons. On the other hand, Srikandi (2007) shows that profit-sharing is positively and significantly related to the quality of the relationship, which means the more mutual benefit received, the better the quality of the relationship between the company and the dealer or marketing intermediaries. Maintenance of the relationship between the company and the dealer must be monitored through the quality of relationships with distributors such as the effectiveness of programs which leads to relationship quality building in order to provide the metric of requirements (Roberts et al., 2003).

Macintosch (2007) suggests that the relationship between customer orientation and the perceived quality of the relationship creates a positive influence to the quality of inter-personal and organizational relationships and customer satisfaction level. In addition, good relationship quality built the company will be able to increase the satisfaction of partners or suppliers. Based on these facts, it can be concluded that good quality of relations that the company have will be able to give satisfaction to partners or consumers. Therefore, the following hypothesis can be built:

H3: Mutual benefit affects the quality of the relationship.

Social benefits have significant and positive effect, meaning that the higher the mutual benefit received, the higher the perceived satisfaction will be (Henning-Thurau et al., 2002). Research findings by Srikandi (2007) show that the distribution of profits has significant and positive effect on satisfaction. This means the better the mutual benefit between companies or craftsmen and their partners or resellers, the more satisfied the resellers will be, which in turn ensures a long-term cooperation. Based on these descriptions, the hypothesis built is:

H4: The quality of relationship affects satisfaction.

Robinette (Srikandi, 2007) states that when each cooperating party is equally benefited from the enterprise, satisfied, and happy with the products and services provided by the company, then the company will benefit. There are three advantages in this, namely confidence, social and special treatment, the quality of relationships in the understanding of loyalty (Henning-Thurau et al., 2002). Based on the explanation above, the built hypothesis is: 
H5: Mutual benefit effects on satisfaction.

Satisfaction can be built on the confidence and the quality of relationship between companies and suppliers within their partnership. In this study, the overall satisfaction is observed from quality of service, price, and overall requirements of the partner met by the company and satisfaction of the agent or dealer by the performance of the company. (Andersen et al., 1990). Based on the description above, the hypothesis built is:

H6: Mutual benefit affects loyalty.

Satisfaction is shown to positively and significantly affects loyalty. This means that the higher satisfaction the consumers have from consuming a product, the higher the customer loyalty will be (Cristobal et al., 2007). Research findings by Lantieri (2008) also confirm that satisfaction is positively and significantly related to loyalty. Based on these descriptions, the built hypothesis is:

H7: Satisfaction affects loyalty.

See Figure 1 for the empirical model of our research.

\section{RESEARCH MODEL}

This research was carried out by method of survey, conducted from March to June 2014. The population in this study comprises of batik SMEs dealers in Semarang. The population is selected due to the fact

Figure 1. Empirical model of the research

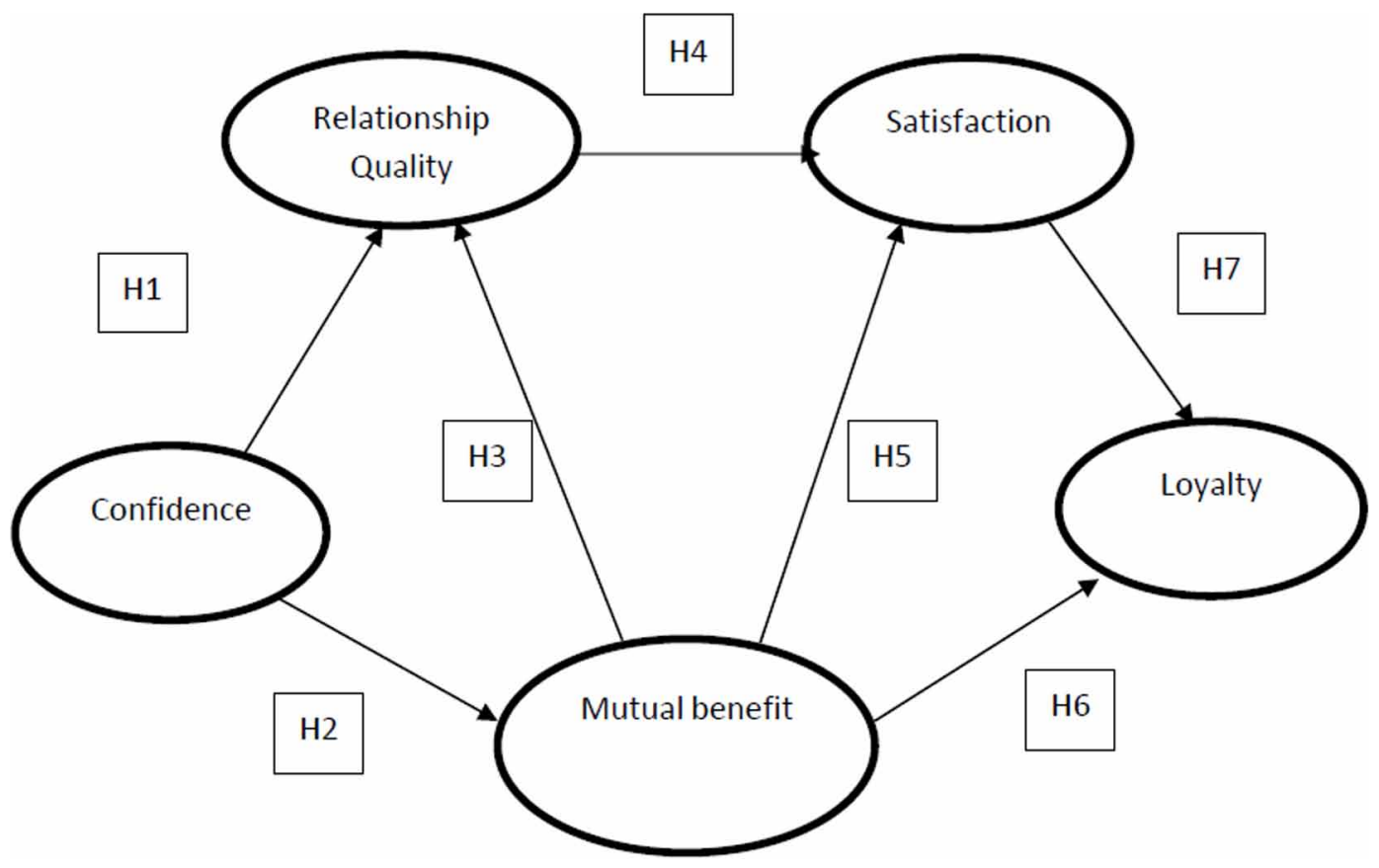


that there has been a marked increase in the number of batik dealers in Semarang, yet these dealers have not shown efficacy in terms of product marketing. The samples in this study are collected from batik dealers in Semarang. The sampling technique employed in this study is purposive sampling with criteria of 1) the respondent has been operating as a dealer for at least one year, 2) the dealer is located within the vicinity of Semarang and is willing to be interviewed. Accidental sampling is carried out for the respondent samplings. There were 131 respondents. The data used in this study are obtained from primary data through questionnaires and secondary data from the scientific literature, international journals, data from government agencies and SMEs, and scientific publications.

Variables used in this research are confidence, relationship quality, mutual benefit, satisfaction, and loyalty. Confidence, which is defined as the willingness to entrust partners in a transaction with the indicators of 1.) honesty, 2.) transparency, and 3) trust (Morgan and Hunt, 1994; Moorman et al., 1992 and Henning -Thurau et al., 2002). The variable of relationship quality is a company established relationships with other parties which considers matters relating to the continuity of relationships and long-term goals, indicated by 1.) communication, 2) conflict, and 3) commitment (De Wulf and Smith, 1998). Mutual benefit is defined as the benefits received and maintained relationship that may not have happened without established relationship, with the indicators of 1.) financial profit, 2) social advantages, and 3.) special treatment (Henning-Thurau et al., 2002). Satisfaction variable is a positive impact as a result of the performance of the company indicated by 1.) service satisfaction, 2) satisfaction levels, and 3) overall satisfaction (Henning-Thurau et al., 2002 and De Wulf and Odeskeben, 2000). Loyalty variable is a positive attitude towards something which leads to consistent and repeated purchase over time, with the indicators of 1.) fidelity, 2.) Word of Mouth communication, 3) recommendation to others (Singh \& Sirdeshmukh, 2000).

\section{Descriptive Data of the Respondents}

Majority of the respondents observed in this study were female with 98 people or $74.81 \%$. Male respondents were accounted for as much as 33 individuals or 20.19\%. Most respondents are of 46 years up to 51 years of age. The number of respondents with high school diploma education level is shown to be dominantly present in the population with as many as 66 people or $50.38 \%$. Most respondents are found to be entrepreneur, with 110 people, or $83.97 \%$, engaged in the profession. 67 respondents or $51.15 \%$ claim to possess experience in Batik marketing for more than 5 years. Monthly batik product sales figure shows that 85 respondents can sell at least 150 pcs or $64.89 \%$. In addition, 67 people or $51.15 \%$ have a working life as a distributor of more than 5 years. Looking at the type of work, the majority of respondents are entrepreneur with as many as 110 people or $83.97 \%$, most of whose profit each month are at the approximate level of $\operatorname{Rp} 2,500,000$.

\section{Descriptive Variables}

The questionnaire in this study employs a 7 Likert scale with each variable broken down into several items of question. The total average of the answers from each respondent is grouped into class intervals:

Interval $=\frac{\text { Maximum Value }- \text { Minimum Value }}{\text { Number of classes }}$

Interval $=\frac{7-1}{7}=0.85$

Based on the data, respondent opinion criteria distribution scales can be specified for the study variables as the following: 
1. Interval 1:00 to 1.85; The respondent has a very low perception of the variables of confidence, relationship quality, mutual benefit, satisfaction and loyalty;

2. Interval 1.86 to 2.71 ; the respondents have a low perception of the variables of confidence, relationship quality, mutual benefit, satisfaction and loyalty;

3. Interval 2.72 to $3: 57$; the respondents have somewhat lower perception of the variables of confidence, relationship quality, mutual benefit, satisfaction and loyalty;

4. Interval 3:58 to 4:43; the respondents have a neutral perception of the variables of confidence, relationship quality, mutual benefit, satisfaction and loyalty;

5. Interval 4:44 to 5:29; the respondents have rather high perception of the variables of confidence, relationship quality, mutual benefit, satisfaction and loyalty;

6. Interval 5:30 to 6:15; the respondents have a high perception of the variables of confidence, relationship quality, mutual benefit, satisfaction and loyalty;

7. Interval 5:30 to 6:15; the respondents have a very high perception of the variables of confidence, relationship quality, mutual benefit, satisfaction and loyalty.

\section{Confidence Variable (KPC)}

Table 1 shows that, in general, the confidence of respondents in this research sit at an average score of 5.77. This indicates that the respondents have a high average perception of confidence. The item which receives the highest response is (KPC7) or the dealer believes that the craftsmen are willing to cooperate, at 6.13, and (KPC9) that the craftsmen are willing to support activities related to cooperation at 6.13. This illustrates that the dealers have a high confidence towards the craftsmen or SMEs in terms of good product quality. On the other hand, (KPC1) receives the lowest score at 5.21,

Table 1. Description of confidence variable

\begin{tabular}{|c|c|c|c|c|c|c|c|c|c|c|c|c|c|c|c|}
\hline \multirow{3}{*}{ Indicator } & \multicolumn{14}{|c|}{ Respondent Score } & \multirow{3}{*}{ Average } \\
\hline & \multicolumn{2}{|c|}{ VUH (1) } & \multicolumn{2}{|c|}{ UH (2) } & \multicolumn{2}{|c|}{ LUH (3) } & \multicolumn{2}{|c|}{$\mathbf{N}(4)$} & \multicolumn{2}{|c|}{ ALH (5) } & \multicolumn{2}{|c|}{ H (6) } & \multicolumn{2}{|c|}{ VH (7) } & \\
\hline & $\mathbf{F}$ & $\%$ & $\mathbf{F}$ & $\%$ & $\mathbf{F}$ & $\%$ & $\mathbf{F}$ & $\%$ & $\mathbf{F}$ & $\%$ & $\mathbf{F}$ & $\%$ & $\mathbf{F}$ & $\%$ & \\
\hline KPC1 & 0 & 0.00 & 18 & 13.74 & 16 & 12.21 & 1 & 0.76 & 3 & 2.29 & 71 & 54.20 & 22 & 16.9 & 5.21 \\
\hline KPC2 & 0 & 0.00 & 0 & 0.00 & 4 & 3.05 & 1 & 0.76 & 7 & 5.34 & 93 & 70.99 & 26 & 19.85 & 6.04 \\
\hline KPC3 & 0 & 0.00 & 6 & 4.58 & 14 & 10.69 & 3 & 2.29 & 17 & 12.98 & 80 & 67.18 & 16 & 12.21 & 5.40 \\
\hline KPC4 & 0 & 0.00 & 18 & 13.74 & 5 & 3.82 & 1 & 0.76 & 3 & 2.29 & 88 & 67.94 & 30 & 22.90 & 5.42 \\
\hline KPC5 & 0 & 0.00 & 16 & 12.21 & 0 & 0.00 & 1 & 0.76 & 3 & 2.29 & 89 & 67.94 & 22 & 16.79 & 5.64 \\
\hline KPC6 & 0 & 0.00 & 7 & 5.34 & 1 & 0.76 & 1 & 0.76 & 6 & 4.58 & 86 & 65.65 & 30 & 22.90 & 5.93 \\
\hline KPC7 & 0 & 0.00 & 1 & 0.76 & 0 & 0.00 & 1 & 0.76 & 3 & 2.29 & 100 & 76.34 & 26 & 19.85 & 6.13 \\
\hline КРC8 & 0 & 0.00 & 0 & 0.00 & 6 & 4.8 & 2 & 1.53 & 8 & 6.11 & 87 & 66.41 & 28 & 21.37 & 5.98 \\
\hline КРC9 & 0 & 0.00 & 1 & 0.76 & 0 & 0.00 & 2 & 1.53 & 2 & 1.53 & 99 & 75.57 & 27 & 20.61 & 6.13 \\
\hline \multicolumn{15}{|c|}{ Variable Average } & 5.77 \\
\hline
\end{tabular}

Description:

KPC1: All the products marketed are acquired from craftsmen.

KPC2: Batik products are produced in accordance with the standards of quality by craftsmen.

KPC3: Acquisition of products from craftsmen is in a timely manner.

KPC4: Management is made transparent to the craftsmen.

KPC5: Price bidding by the distributor is made transparent to the craftsmen.

KPC6: Difficulties faced by the distributor is openly communicated.

KPC7: The dealer is confident that the craftsmen are willing to enter a partnership.

KPC8: The dealer is confident that producers are able to meet the needs of batik products.

KPC9: The dealer is confident that producers are willing to support activities related to their partnership. 
which suggest that dealers do not only collect and resell batik products from a certain craftsman or a certain group of craftsmen in Semarang.

\section{Relationship Quality Variable (KH)}

Relationship quality variable $(\mathrm{KH})$ in this research scores at 5.85. This indicates that respondents believe that they have high quality relationships with their craftsmen or SMEs. The item which receives the highest response is the ability of dealers to maintain good relations with craftsmen (KH9) at 6.21. This indicates that respondents feel that they should maintain quality relationships with the majority of SMEs craftsman or dealer and only sell products with consignment system, meaning that the dealer pays the value of the product to the craftsman or SMEs once a product has been sold. The item with the lowest response is regular dealer meetings with craftsmen (KH2) at 5.15. This illustrates that the quality of the relationship is rather high among dealers with craftsmen, considering that the dealer meets with her craftsman / craftsmen every time a product is sold.

\section{Mutual Benefit Variable}

Mutual Benefit Variable (PK) score 5.45 in this study. This fact indicates that respondents believe that mutually benefit cooperation is very important. Establishing close relationship with the craftsmen (PK4) item scores the highest in this category at 6.05. Distributors believe that a well-established relationship with the craftsmen is key to obtaining the desired batik products. However, providing the best facilities to the craftsmen (PK7) rates the lowest at 4.50, reflecting the fact that respondent has not been the best facilitators of the craftsmen.

\section{Satisfaction Variable}

Satisfaction Variable (KPS) is scored at 5.88 in this study, showing the fact that that the respondents have obtained a rather high satisfaction level. Highest responded items are (KPS7) and (KPS8) which equally rated at 6.18 . This fact suggests that the cooperation between the respondents and craftsmen as partners is perceived as reliable and professional in nature. The cover fee payment period (KPS5) receives the lowest value at 5.43. This fact reflects the neutrality of respondents towards the time given to pay for the cover fee, in which case is short at times and often arrives before any product is sold.

Loyalty (LY) scores at 5.02, which indicates that the respondents have a rather high loyalty. The item that receiving the highest response is the desire of respondents to be committed in a longterm relationship with the craftsmen or SMEs (LY3), which is rated at 6.05. The lowest response is obtained from the item recommendation to colleagues to get in touch with the craftsmen (LY7), with a value of 3.95. The data reflect how low the loyalty level of respondents is when it comes to referring their batik craftsmen or SMEs since the respondents have to compete for an advantage of a steady supplier (see Table 2).

\section{THE RESULTS OF HYPOTHESIS TESTING}

The basis used in testing the hypothesis in this research is the value in the output result for the inner weight In PLS with which every relationship hypothesized is statistically simulated. In this case, the hypothesis testing was conducted using bootstrap resampling. Testing with bootstrapping is also intended to minimize problems with abnormalities in research data. Application of resampling method allows the entry of freely distributed data (distribution free), which does not require the assumption of a normal distribution, and does not require a large sample. Statistical test used was t test. The significance of the estimated parameters provides very useful information about the relationship between the study variables. Figure 2 presents a research model that is fit through the process of validity and reliability testing (outer model). 
Table 2. Path coefficients (mean, STDEV, T-values)

\begin{tabular}{|l|l|l|l|l|l|}
\hline & $\begin{array}{c}\text { Original Sample } \\
(\mathbf{O})\end{array}$ & \multicolumn{1}{|c|}{$\begin{array}{c}\text { Sample Mean } \\
(\mathbf{M})\end{array}$} & \multicolumn{1}{|c|}{$\begin{array}{c}\text { Standard } \\
\text { Deviation } \\
(\text { STDEV) }\end{array}$} & $\begin{array}{c}\text { Standard Error } \\
\text { (STERR) }\end{array}$ & $\begin{array}{c}\text { T Statistics (IO/ } \\
\text { STERRI) }\end{array}$ \\
\hline KH-> KPS & 0.400962 & 0.397304 & 0.091563 & 0.091563 & 4.379062 \\
\hline KP -> KH & 0.228559 & 0.241814 & 0.076958 & 0.076958 & 2.969898 \\
\hline KP -> PK & 0.467280 & 0.505707 & 0.065519 & 0.065519 & 7.132001 \\
\hline KPS -> LY & 0.329069 & 0.330241 & 0.077724 & 0.077724 & 4.233838 \\
\hline PK -> KH & 0.471849 & 0.462177 & 0.088136 & 0.088136 & 5.353629 \\
\hline PK -> KPS & 0.291045 & 0.307730 & 0.085048 & 0.085048 & 3.422124 \\
\hline PK -> LY & 0.382129 & 0.388851 & 0.085951 & 0.085951 & 4.445908 \\
\hline
\end{tabular}

Figure 2. Path output diagram (post model fit)

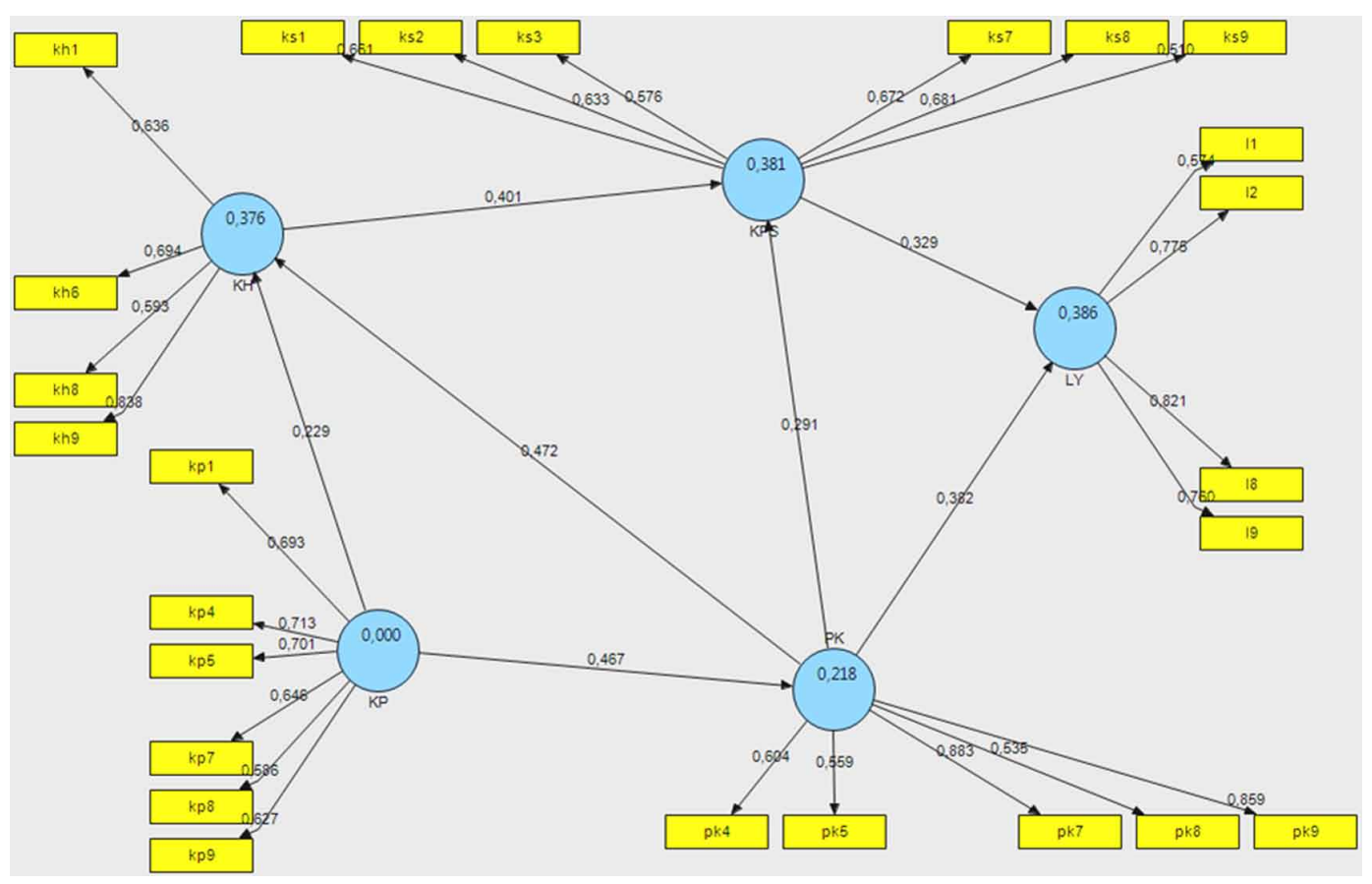

Once the model is fit, the bootstrapping resampling analysis is performed to test the hypotheses. Presented in Table 3 are the path coefficients for testing previously proposed hypotheses.

Bootstrapping hypothesis testing results of the PLS analysis in Table 3 confirm that all hypotheses are accepted. H1, Confidence affects the quality of the relationship, has a significance level of 5\%, a t-table value of 1.978 and a t-statistic value of 4.232181 . It can be seen that the t-statistic is greater than the t-table value, thus it can be concluded that $\mathrm{H} 1$ is accepted. Based on the data in Table 3, it can also be seen that the coefficient on $\mathrm{H} 1$ is positive 0.228559 , which confirm the positive effect of confidence towards relationship quality.

$\mathrm{H} 2$ proposes that confidence affects mutual benefit in the partnership between dealers and craftsmen or SMEs, with a significance level of 5\%, t-table of 1.978 and t-statistic of 9.187448. It can 
Table 3. Hypothesis testing

\begin{tabular}{|l|l|l|l|l|l|}
\hline \multicolumn{1}{|c|}{ Hypothesis } & Coefficient & \multicolumn{1}{c|}{ Significance Level } & T-Table & T-Statistics & \multicolumn{1}{c|}{ Results } \\
\hline H1 & 0.228559 & $5 \%$ & 1.978 & 2.969898 & H1 accepted \\
\hline H2 & 0.467280 & $5 \%$ & 1.978 & 7.132001 & H2 accepted \\
\hline H3 & 0.471849 & $5 \%$ & 1.978 & 5.353629 & H3 accepted \\
\hline H4 & 0.400962 & $5 \%$ & 1.978 & 4.379062 & H4 accepted \\
\hline H5 & 0.291045 & $5 \%$ & 1.978 & 3.422124 & H5 accepted \\
\hline H6 & 0.382129 & $5 \%$ & 1.978 & 4.445908 & H6 accepted \\
\hline H7 & 0.329069 & $5 \%$ & 1.978 & 4.233838 & H7 accepted \\
\hline
\end{tabular}

be seen that the t-statistic is greater than the t-table, thus it can be concluded that the $\mathrm{H} 2$ is accepted. Based on the data in Table 3, it can also be seen that the coefficient of $\mathrm{H} 2$ is positive on 0.467280 , which reinforces the hypothesis that confidence has a positive effect on mutual benefit.

$\mathrm{H} 3$ is a hypothesis regarding how mutual benefit affects the quality of the relationship, with a significance level of 5\%, t-table of 1.978 and t-statistic of 3.928706. It can be seen that the t-statistic value is greater than the t-table value, thus it can be concluded that the $\mathrm{H} 3$ is accepted. Based on the data in Table 3, it can also be seen that the coefficient of $\mathrm{H} 3$ is positive with the value of 0.471849 . Therefore, it can be concluded that the mutual benefit has a positive effect on relationship quality.

$\mathrm{H} 4$ proposes that the quality of relationship affects satisfaction. With a significance level of 5\%, t-table of 1.978, and t-statistic of 3.486806, it can be seen that the t-statistic is greater than the t-table, suggesting that $\mathrm{H} 4$ is accepted. Based on the data in Table 3, it can also be seen that the coefficient of $\mathrm{H} 4$ is positive with the value of 0.400962 . Therefore, it can be concluded that the quality of relationship affects satisfaction.

H5 states that mutual benefit affects on satisfaction. With a significance level of 5\%, t-table value of 1.978 , and t-statistic value of 3.047525 , it can be seen that the $t$-statistic is greater than the t-table, rendering H5 accepted. Based on the data in Table 3, it can also be seen that the coefficient of $\mathrm{H} 5$ is positive with the value of 0.291045 , which suggest that mutual benefit is positively related to satisfaction.

H6, which postulates that mutual benefit affects loyalty, has a significance level of 5\%, t-table value of 1.978, and t-statistic value 2.461057. Considering that the t-statistic is greater than the t-table, it can be concluded that H6 is accepted. Based on the data in Table 3, it can also be seen that the coefficient of H6 is positive with the value of 0.382129 . Therefore, it is confirmed that mutual benefit positively related to loyalty.

$\mathrm{H} 7$ states that satisfaction affects loyalty, with a significance level of 5\%, t-table value of 1.978 , and t-statistic value of 2.461057. From the data in Table 3, it can be seen that t-statistic value is greater than the t-table value. Thus, it can be concluded that the $\mathrm{H} 7$ is accepted. The data also shows that the coefficient of $\mathrm{H} 6$ is positive with the value of 0.329069 , which means that satisfaction has a positive influence on loyalty.

\section{RESEARCH FINDING AND THEORETICAL IMPLICATION}

Based on the results of this study, the following can be concluded.

Firstly, that confidence (KP) is positively and significantly related to mutual benefit (PK) is proven. In terms of the path coefficients, results indicate a strong influence of confidence in the partnership 
between craftsmen with dealers. This fact has an important role related to the sharing of benefits that have been promised, in that the level of confidence the craftsmen have on the dealers affect the profit made by the dealers. This allows long-term partnership to be established, which in turn may create loyalty of dealers and ensure that they do not turn to competitor craftsmen. This result is in accordance with the results in Bitner (1995), De Wulf and Odeskeben (2000) and Robinetee (2000).

Secondly, the high value of the quality of relationships $(\mathrm{KH})$ means that it is positively and significantly related to satisfaction (KPS). This means that the higher the quality of the relationship established by the dealer, the higher satisfaction of craftsmen or SMEs will be. This is supported by the findings of the study (Robert et al., 2003; Macintosch, 2007; and Gilbert and Judith, 2011) which states that the quality of the relationship has positive and significant impact on satisfaction. While low value of the relationship between confidence (KP) and mutual benefit (PK) means that the higher the confidence between craftsmen or SMEs and dealers, the more mutual benefit is earned between them. The results of this study can provide input on policy makers to design and develop policies for the development of small and medium enterprises in the sector of batik handicrafts and fashion.

\section{Managerial Implication}

Based on the results of hypothesis testing, overall variables in the existing empirical models with PLS analysis techniques are found to be acceptable. The implications of the findings in this research towards the application of relationship marketing are:

- $\quad$ Firstly, effort should be made to increase the confidence between suppliers and dealers who help market the product. The more confidence craftsmen have on their dealers, the higher satisfaction the craftsmen or SMEs will get;

- Secondly, to ensure a long-term partnership between the enterprising parties, the quality of relationship between suppliers and craftsmen or Small and Medium Enterprises (SMEs) should be enhanced, so that the satisfaction of craftsmen or SMEs will be the better;

- Thirdly, Craftsmen or SMEs should be more transparent in determining the mutual benefit with suppliers to improve satisfaction so as to create a profitable partnership for both enterprising parties;

- Fourthly, satisfaction of dealers with craftsmen or SMEs should be increased so that the craftsman or SMEs can provide and meet the required product requested by the dealers in a timely manner.

\section{Limitations and Further Research}

This study is the use of a sample or batik dealer respondents in Semarang, which was purposively sampled thereby it cannot describe or generalize Batik dealer in Semarang city as a whole. This study is not conducted through a comprehensive in-depth interview; therefore it may not provide comprehensive insight and information, particularly with regard to indicators of each variable.

Further research related to relationship marketing is to be conducted, particularly on the relationship between SMEs or manufacturers and consumers or (BtoC). The further research should be focused on aspects of craftsmen or SMEs by adding variables and market sensing capabilities of the market in terms of its relevance to the performance of the marketing of craftsman or SMEs that have implemented relationship marketing. Another consideration is the need to study the addition of a partnership with suppliers so that it can be done through long-term cooperation or relationship to be comprehensive and between the two sides. 


\section{REFERENCES}

Andersen, J., \& Narus, J. (1990). A model of distribution firm and manufacturer firm working partnerships. Journal of Marketing, 54(1), 42-58. doi:10.2307/1252172

Ardyan, E., Rahmawan, G., \& Isstianto, S. (2016). Building entrepreneurial networking quality to improve the success of innovation and Batik SMEs performance. International Journal of Sociotechnology and Knowledge Development, 8(4), 37-54.

Barnes, J. (2001). Secrets of customer relationship management. The McGraw-Hill.

Basheer, A. (2014). Impact of marketing activities on relationship quality in the Malaysian banking sector. Journal of Retailing and Consumer Services, 21, 347-356.

Berry, L. (1983). Relationship marketing. In L.L. Berry, G. Lshostak \& G.D (Eds.), Emerging perspective on service marketing (pp. 25-38). Chicago: Journal American Marketing Association.

Berry, L., \& Parasuraman, A. (1991). Marketing service: competing trough quality, New York: The Free Pass, 131.

Bitner, M. (1995). Building service relationships: It' all about promises. Journal of the Academy of Marketing Science, 23(4), 246-251. doi:10.1177/009207039502300403

Brettel, M., Steffen, S., \& Tessa, F. (2012). Improving the performance of business model with relationship marketing efforts- an entrepreneurial perspective. European Management Journal, 30(2), 85-98. doi:10.1016/j. emj.2011.11.003

Buttle, F. (2007). Customer relationship management concept and tool. Elsevier Worth Heineman.

Cristobal, E., Flavian, C., \& Guinaliu, M. (2007). Perceived e-service quality (PeSQ): Measurement validation and effect on consumer satisfaction and website loyalty. Journal Managing Service Quality, 17(3), 317-340. doi:10.1108/09604520710744326

Cruceru, F., \& Moise, D. (2014). Customer relationships through sales forces and marketing events. Procedia: Social and Behavioral Sciences, 109, 155-15. doi:10.1016/j.sbspro.2013.12.436

DeWulf, Kristof, \& Gaby, O. (2000). The Infuence seller relationship orientation and buyer relationship proneness on trust commitment and behavioural loyalty in a consumer evirontment. European Journal of Marketing, 12, 230-264.

Doney, P., \& Cannon, J. (1997). An examination of the nature of trust in buyer-seller relationships. Journal of Marketing, 61(2), 35-51. doi:10.2307/1251829

Dwyer, F., Schur, P., \& Oh, S. (1987). Developing buyer-seller relationship. Journal of Marketing, 5(2), 11-27. doi: $10.2307 / 1251126$

Farida, N. (2017). Antecendent of innovation and marketing performance in Batik Industry. Advanced Science Letters, 23(1), 471-474. doi:10.1166/asl.2017

Garbarino, Ellen, Johnson, \& Mark, S. (1999). The different roles of satisfaction, Trust, and commitment in customer relationships. Journal of Marketing, 63, 70-87. doi:10.2307/1251946

Gilbert, N., \& Judith, M. (2011). Relationship quality and performance outcomes: Achieving a sustainable competitive advantage. Journal of Business Logistics, 32(4), 345-360. doi:10.1111/j.0000-0000.2011.01030.x

Gronroos, C. (1994). From marketing mix to relationship marketing: Toward a paradigm shift in marketing. Journal Management Decesion, 32(2), 4-20. doi:10.1108/00251749410054774

Hair, J. F., Jr., Anderson, R. E., \& Tatham, R. L. dan Black, W.C. (1998). Multivariate Data Analysis. Fifth edition. New Jersey: Prentice Hall, Inc.

Hennig-Thurau, T., Gwinner, K. P., \& Gremler, D. D. (2002). Understanding relationship marketing outcomes an integrations of relational benefits and relationship quality. Journal of Service Research, 4(3), $230-246$. doi:10.1177/1094670502004003006 
Jia, F., \& Jeff, J. (2013). Marketing channel relationships in china: A review and integration with an institutionbased perspective. Journal of Business Esearch, 66, 2545-2551.

Kanibir, H., Reha, S., \& Sim, N. (2014). Determining the antecedent of marketing competencies of SMEs for international market performance. Procedia: Social and Behavioral Sciences, 150, 12-23. doi:10.1016/j. sbspro.2014.09.003

Kumar, V., Dalla, P., Jandrew, P., \& Denish, S. (2009). Reversing the logic: The path to probitability through relationship marketing. Journal of Interactive Marketing, 23(2), 147-156. doi:10.1016/j.intmar.2009.02.003

Lantieri, T. (2008). Variable relationships in online retailing: cultivating consumer satisfaction and loyalty. Lubin, Italy: Pace University.

Lin, N., Weng, J., \& Yi-Ching, H. (2003). Relational bonds and customer's trust and commitment. A study on the moderating effect of web site usage. Service Industries Journal, 23(3), 103-124. doi:10.1080/714005111

Lindgreen, A., \& Antioco, M. (2003). Customer relationship management: one European bank's experiences, Departement of Marketing. Catholic University of Louvain Belgium.

Macintosh, G. (2007). Customer orientation, relationship quality and relational benefit to the firm. Journal of Services Marketing, 21(3), 150-159. doi:10.1108/08876040710746516

Moorman, C., \& Deshapande, R. (1992). Relationship between providers and user of market research: The dynamics of trust within and between organizations. Journal of Marketing Reseach, 29(3), 314-328. doi: $10.2307 / 3172742$

Morgan, M., \& Hunt, S. (1994). The commitment-trust theory of relationship marketing. Journal of Marketing, 58(3), 20-38. doi:10.2307/1252308

Palmer, A. (2002). The evolution of on idea: An evironmental explanation of relationship marketing. Journal of Relationship Marketing, 1(1), 79-94. doi:10.1300/J366v01n01_06

Robert, W., Lisa, K., \& Mark, B. (2007). Use relationship marketing programs in building customer-salesperson and customer-firm relationships: Differential influences on financial outcomes. International Journal of Research in Marketing, 24(3), 210-223. doi:10.1016/j.jjresmar.2006.12.006

Robinette, S. (2000). Emotion marketing. Singapore: McGraw Hill Book Company.

Schneider, B., Ehrhart, M. G., Mayer, D. M., Saltz, J. L., \& Niles-Jolly, K. (2005). Understanding organizationcustomer links in service settings. Academy of Management Journal, 48(6), 1017-1032. doi:10.5465/ AMJ.2005.19573107

Singh, J., \& Sirdeshmukh, D. (2000). Agency and trust mechanisms customer satisfaction and loyalty judgment. Journal of the Academy of Marketing Science, 28(1), 150-167. doi:10.1177/0092070300281014

Skarmeas, D., \& Constantine, S., Katsikeas., Stayroula., \& Esmai, S. (. (2008). Market and supplier characteristic driving. Journal Industrial Marketing Management, 37, 23-36. doi:10.1016/j.indmarman.2007.04.004

Smith, J. (2008). Buyer-seller relationship: Similarity, relationship management, and quality. Psychology and Marketing, 15(1), 3-21. doi:10.1002/(SICI)1520-6793(199801)15:1<3::AID-MAR2>3.0.CO;2-I

Srikandi, K. (2007). Relationship marketing dalam bentuk kemitraan usaha antara pemasok dan penyalur pada koperasi susu di propinsi Jawa Timur. Universitas Brawijaya, Malang Indoesia. 
Farida Naili has served as a lecturer at the Doctoral Program of Social Sciences, University of Diponegoro in Semarang, Indonesia since 1990. She began her research in 1995. Her areas of research include Marketing, Consumer Behaviour, SMEs, and Entrepreneurship. She has been published in several journals, including: Jurnal Keuangan dan Perbankan, Volume 14,No. 2,pp. 221-230 (Indonesia Higher Education Indexed), Market Trzste, Vol.27No.2, pp.189-202 (Scopus Index), Journal of Internet Banking and Commerce (Scopus Index), Vol.21, No.2, pp. 1-19, Dinamika Manajemen, Vol.No.2. pp. 200-208., and Jurnal Dinamika Manajemen, Vol. 7.No.1 (Indonesia Higher Education Indexed). She has participated in several international conferences, like: The 3 rd Interntional Confrence on Business and Banking of Thailand, 2014, The 1 st Internastional Conferen on Business Administration and Policy, University of Indonesia, 2015, 2016 Advanced Research on Business, Management and Humanities, 2016, and the International Conference on Management in Emerging maket 2016. She became an Editorial Member of Journal of Business Administration and Editorial Board member of Jurnal Dinamika Manajemen (Indonesia Higher Education Indexed), in 2016.

Agus Naryoso, MSi, has served as a lecturer and researcher at Diponegoro University Semarang, Indonesia, since 2002. His areas of research include communication, public speaking, integrated marketing communication, marketing public relations. His studies have been published in the Indonesia journal Public Relations Model in Semarang Senior High School Vol. 1 No. 1, pp. 12-24, Journal of Ikatan Sarjana Komunikasi Indonesia (ISKI). $\mathrm{He}$ also has participated in several international conferences, including: (1) International Conference of Public Management 2016, China; (2) National Seminar: Political Gender and development in Indonesia, Sebelas Maret University Solo 2015; (3) The 1st UPI International Conference on Sociology Education (UPI ICSE) Bandung 2015; and (4) National Health Communication Symposium, Padjajaran University, Bandung 2015. Agus Naryoso is Editor in Chief of FORUM Jurnal Pengembangan IImu Sosial Faculty of Social and Politic Sciences Diponegoro University. $\mathrm{He}$ is also the Head of Public Relations Diploma Faculty of Social and Politic Sciences Diponegoro University.

Elia Ardyan, MBA is a lecturer and researcher at Sekolah Tinggi Ilmu Ekonomi Surakarta, Indonesia. He begin to be lecturer dan researcher from 2011 until now. His area research in entrepreneurship, small medium entreprises, marketing. His studies published in Indonesia journal and international journal (International Journal of Online Marketing, Vol. 4, Iss. 4, pp. 36-51; International Journal of Innovation Digital Economy (IJIDE) vol. 6, Iss. 2. Pp, 38-51; Market/Tržište Vol. 27, No. 2, pp. 189-202 (Scopus Index); DLSU Business \& Economics Review, Vol. 25, No. 2., pp. 79-97 (Scopus Index); International Journal of Sociotechnology and Knowledge Development Vol. 8, No. 4, pp. 37-54 (Scopus Index); International Journal of Civil Engineering and Technology Vol. 8, No.8, pp.1114-1122 (Scopus Index); Asia Pacific Management Review- in press (Scopus Index)). 